\title{
口腔・頻・顔面外科における自家血輸血の応用
}

鶴木 隆・市ノ川義美・石河信高・吉岡弘道 張陽明・中野洋子・本間義章・丸森雅由 高野伸夫・松井隆・辛暁根・高橋庄二郎

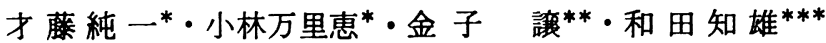

\section{Application of autotransfusion to oral and maxillofacial surgery}

\author{
Takashi Tsuruki - Yoshimi Ichinokawa - Nobutaka Ishikawa \\ Hiromichi Yoshioka - Yang-Ming, Chang • Yoko Nakano \\ Yoshiaki Homma - Masayoshi Marumori $\cdot$ Nobuo Takano \\ Takashi Matsui • Hyo-Geun Shin • Shojiro TAKahashi \\ Junichi SaIto* - Marie Kobayashi* - Yuzuru Kaneko** - Tomoo WadA***
}

\begin{abstract}
The risks after homogeneous blood transfusion must be minimized in oral and maxillofacial surgery. The risks include infectious diseases such as posttransfusional hepatitis, adult T-cell leukemia (ATL), acquired immunodeficiency syndrome (AIDS), etc., incompatibility o hemotypes and antibody formation. Autotransfusion is the transfusion of blood of a patient back into himself. We applied autotransfusion in 45 cases of maxillofacial deformities to prevent the above mentioned diseases and side effects since July 1983.
\end{abstract}

No case of posttransfusional hepatitis was encountered and safety of this method was confirmed.

Key words: autotransfusion, posttransfusional hepatitis, AIDS and ATL

緒

\section{言}

口腔外科の手術は䫛顔面骨に侵襲を加えることが多 く，しかも影顔面は解剖学的に血管に富み血流の多い部

東京菌科大学口腔外科学第 2 講坐

（主任：高栝庄二郎教授）

* 東京㐘科大学臨床㭘查室

（主任：中久喜 喬教授）

**東京橉科大学菌科麻酔学講座 （主任：中久喜 喬教授）

***東京菌科大学内科 （主任：和田知雄教授）

The Second Department of Oral and Maxillofacial Surgery (Chief: Prof. Shojiro Takahashi)

* Department of Clinical Laboratory (Chief: Prof. Takashi Nakakuki)

** Department of Dental Aneastesiology, Tokyo Dental College (Chief: Prof. Takashi Nakakuki)

*** Department of Internal Medicine, Tokyo Dental College (Chief: Prof. Tomoo Wada)

受付日：昭和61年 1 月 21 日
位であり，さらに顔面審美性温存の上から可及的に口内 法1)が選択されることから術中出血量が多くなりやす い. とくに影矮正外科中頭蓋顔面外科では咬合や顔面形 態の改善状況を観察しながら精密に手術が行われるた め，手術時間が長くなり，出血量が增加しやすい傾向に ある2).

いかなる外科の 分野でも，術前術後の出血に対して は，必要に応じて同種血輸血が多く行われている。 しか しながら輸血後肝炎は同種血榆血症例の約 $15 \%$ に発生し その大多数が非 A 非 B 型肝炎であるといわれている8 しかも，現在のところ非 $A$ 非 B 型肝炎ウイルスは同定さ れておらず，確実な予防法は見出されていない，このは か愉血により伝播される疾患は数多くあるが，最近，成 人 T 細胞白血病 (ATL $)^{8,8)}$ 中後天性免疫不全症候群 (AIDS) の病原体ウイルスが榆血により高頻度で伝播す ることが明らかとなり ${ }^{10-13)}$ ，これらの疾患が急增してお り，さらにひとたび、これらの疾患が発病すれば，きわ めて重䉆で，しばしば致死的であることから，日常，一 般的に行われている同種血輸血の危険性がにわかに注目 


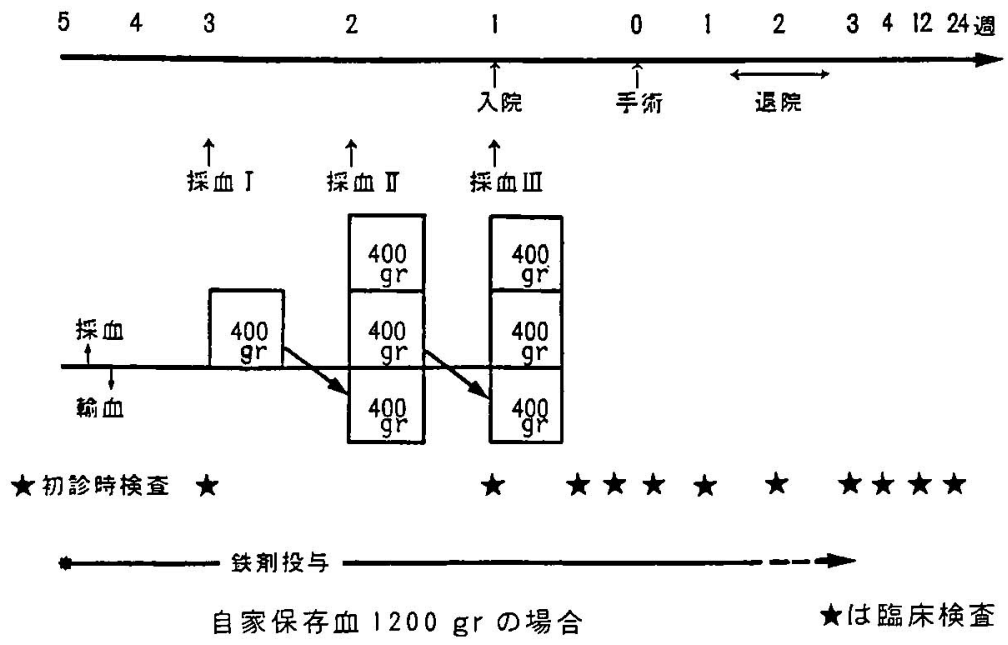

図 1 自家血輸血のスケシュール

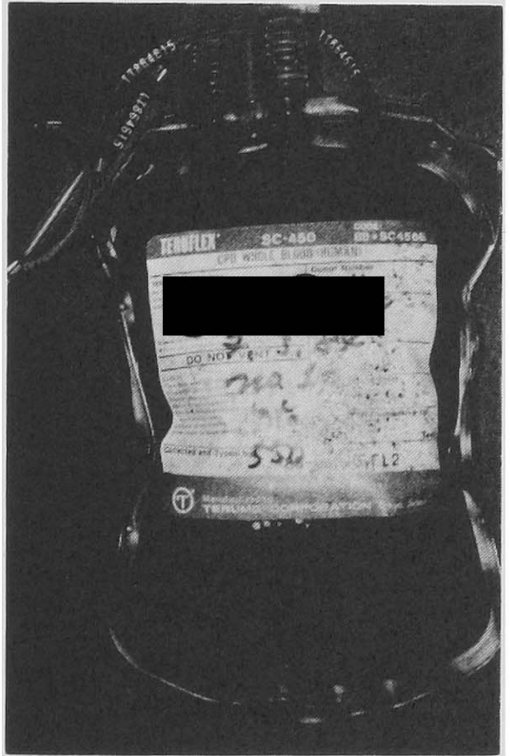

写】 1 採血した血液バック(450 gr)

されるよらになった10〜17).

術中失血に対する同種血輸血の合併症を防止する手段 としては，出血量軽減化による無輸血手術の施行と自家 血輪血 ${ }^{18 \sim 27)}$ の 2 づ考えられる ${ }^{28)}$. 自家血輸血には自家 保存血と自家凍結血を利用する 2 つの方法があるが，前 者は特别の設備や処理を必要とせず小規模な病院です容 易に実施可能である。わたくしたちは 1983 年 7 月より

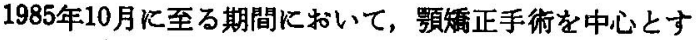
る口腔外科の手術施行患者45症例に自家保存血を用いる 自家血陯血を実施し，十分にその目的を達成するととる
に, 高い安全性を確認することができたので, 本法の概 要を報告する。

対 象

自家血輸血施行患者の選択基準は以下のとおりであ る。

1)特記すべき自覚症状がなく，理学的にも特記すへ き異常所見を認めない。

2）血液検查所見を含を臨床検査所見に異常を認めな い. 特に下記の検查所見に留意する。

(1) 末梢血 $\mathrm{Hb} 12 \mathrm{gr} / \mathrm{d} l$ 以上

Ht $35 \%$ 以上

比重 1.052 以上

(2) 肝機能 GPT $0 \sim 40$ 笚位 GOT $0 \sim 35$ 単位

（3）尿検查

（4）皮应の状熊

輸血用血液の採血前に 1)，2）を検查し，異常のない ことを確認し，㡏血完了後15分以内に非尿させ，血色囊 尿の有無，皮后の出血斑，発沴の有無を検査する。

3）手術日を予め自由に決定でさる(選択手術).

4) 出血量が大略予想でき，㻌血を要する手術.

5）55藏以下で体重 $40 \mathrm{~kg}$ 以上.

自家血渝血の方法

手術前後のスケジニールと採血方法を图 1 に示す. ま ず手術時の出血を予想して総採血量を决定する。すなわ ち抗凝固薬 C.P.D. (Citrate Phosphate Dextrose) 使用 の 全血保存血の 使用期限は採血後 3 週間であるため, 術前 1 週間に 1 回 $400 \mathrm{gr}$, 術前 2 週間に 2 回計 $800 \mathrm{gr}$ 術前 3 週間に 3 回計 $1,200 \mathrm{gr}$ のいずれの量の 自家血を 
表 1 自家血輸血を応用した骨切り手政

1983 年 7 月〜 1985年 10 月

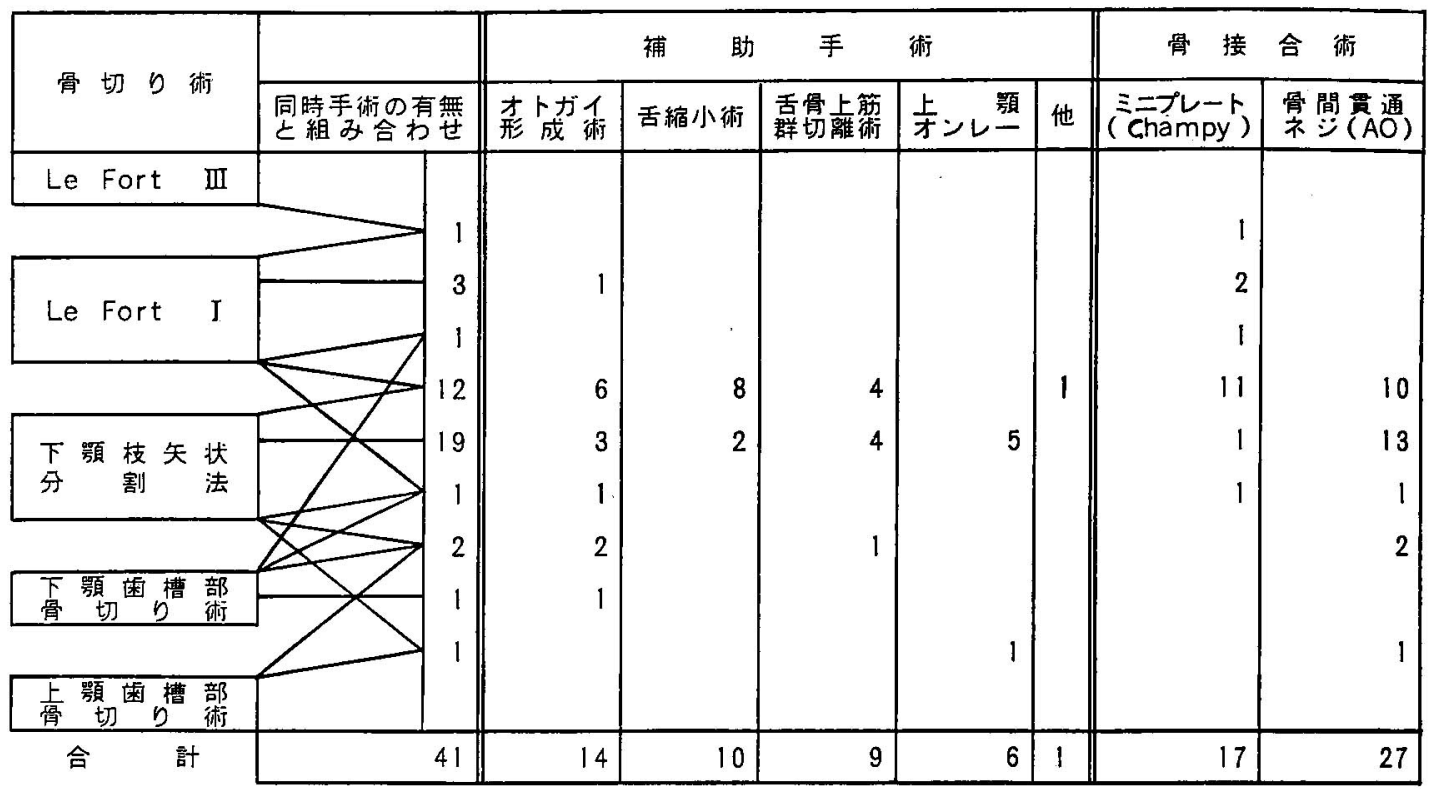

龺京菡科大学口腔外科学第 II 講座

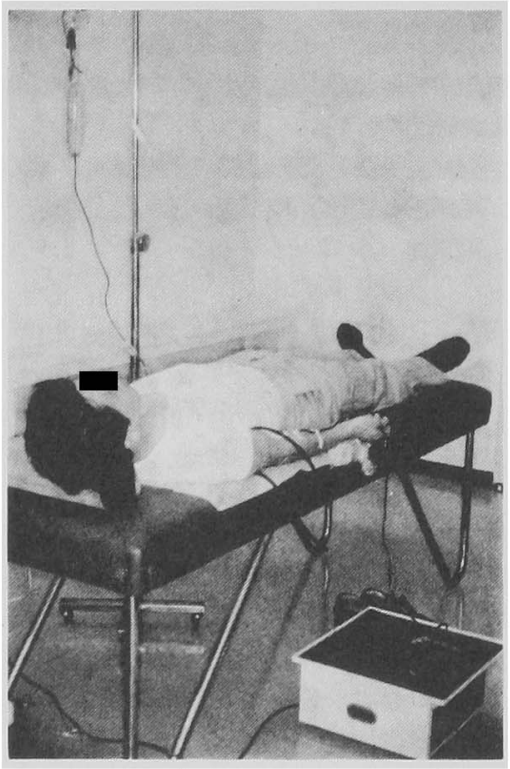

写真 2 採血中の状態 (2 回目)

1 回目採血した自家血を翰血し，新鲜 な血液を採る。

保存すべきかを決める。な扰採血開始の $2 \sim 3$ 週前上り 鉄剤(テックール) $200 \mathrm{mg}$ ，ビタミンC $500 \mathrm{mg}$ を毎日 分 2 で経口投与し, 術直後は経静脈的投与に切り替兄,

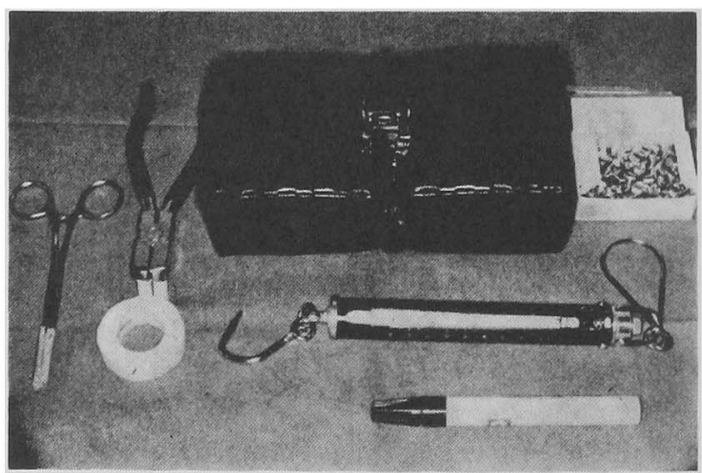

写真 3 採血用具

さらにその後む必要期間経口投与を続ける，また採血決 定後，蛋白質の多い食事を摄取させる，1回採血量は体 重 $50 \mathrm{~kg}$ で $400 \mathrm{gr}$ を基準として $350 \sim 450 \mathrm{gr}$ とし，採血 直後に採血量と同量のブドウ梼加乳酸リンゲル液（ハル トマン液)を榆液する。採血用バックは抗凝固洎 C.P.D. 入り $450 \mathrm{gr}$ 用 (テルモ社製)を使用する（写真1).

採血は通常，上肢皮静脈より行う，まず患者をべット 上飞臥床させ，血圧および脈拍測定後，上腕部に殹血带 をまき，穿刺部位を中心に直径 $10 \mathrm{~cm}$ の皮庙を $70 \%$ 酒 精綿で清拭し，さらに50\%ヒビテンフルコールで 2 回拭

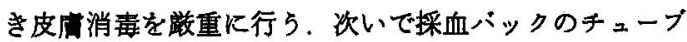
にクレンメをかけ，キャップを外して，針先を末梢側に 

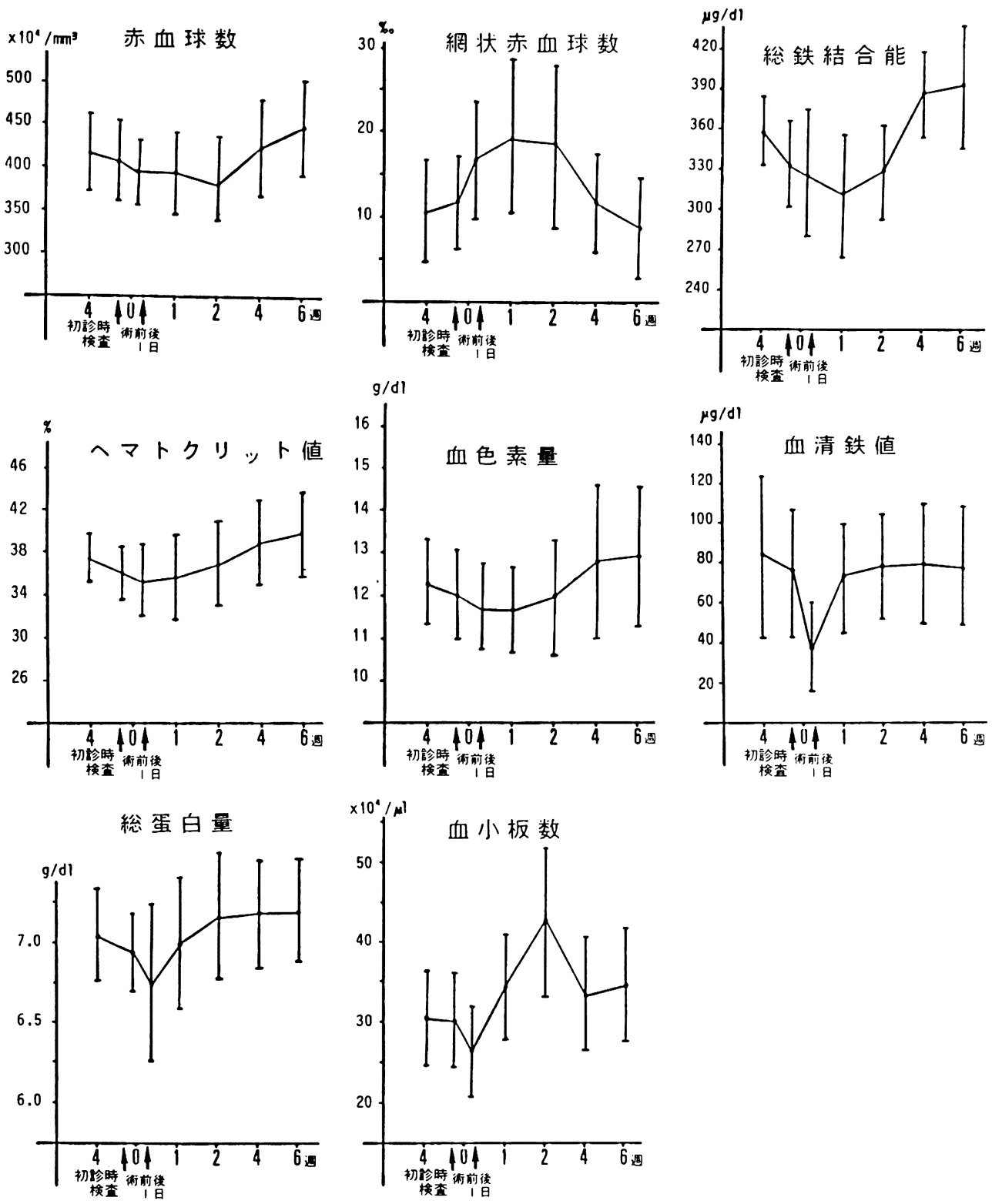

図 2 血液検査成䋶の怪日的变化（45例平均）

向け $16 \mathrm{G}$ の穿刺針を血管内に $10 \mathrm{~mm}$ 程度挿入して絆創 亭にて皮后に固定する。採血はベットの下約 $60 \mathrm{~cm}$ に 設置した振動機上に採血ハックを固き，この落差を利用 して行い，血液と抗凝固薬とをよく混和させる。この 際, 駆血帯の締め具合を調節して採血の効率化をはかる. またときどき，ハックの重量をバネ科で計りつつ，必要 量の採血を行 5。1ハッック採血後，2バック目を採血す る場合，あるいは採血後に輸液する場合には，チューブ にクレンメをかけ，その中权側に穿刺する．採血を終え
たバックには患者名，血液型，採血量，および採血日， 何回目の採血であるかを太い黒マジックインクで書き入 れた後, 血液用冷蔵庫内に $+4^{\circ} \mathrm{C}$ で保存する. 2 回以 上採血する場合には前回採血した $400 \mathrm{gr}$ を加温器（ア ニメック）を用いて輸血した後， $800 \mathrm{gr}$ を採血する，手 術が延期になった場合には保存しておいた血液を患者に 輸血した後，ほぼ同量の採血を行って新鮮な保存血に換 えて保存する。なお採血には専用の清絜な小部屋を使用 し，採血用具は 1 セットとして使用ごとにェチレンオキ 

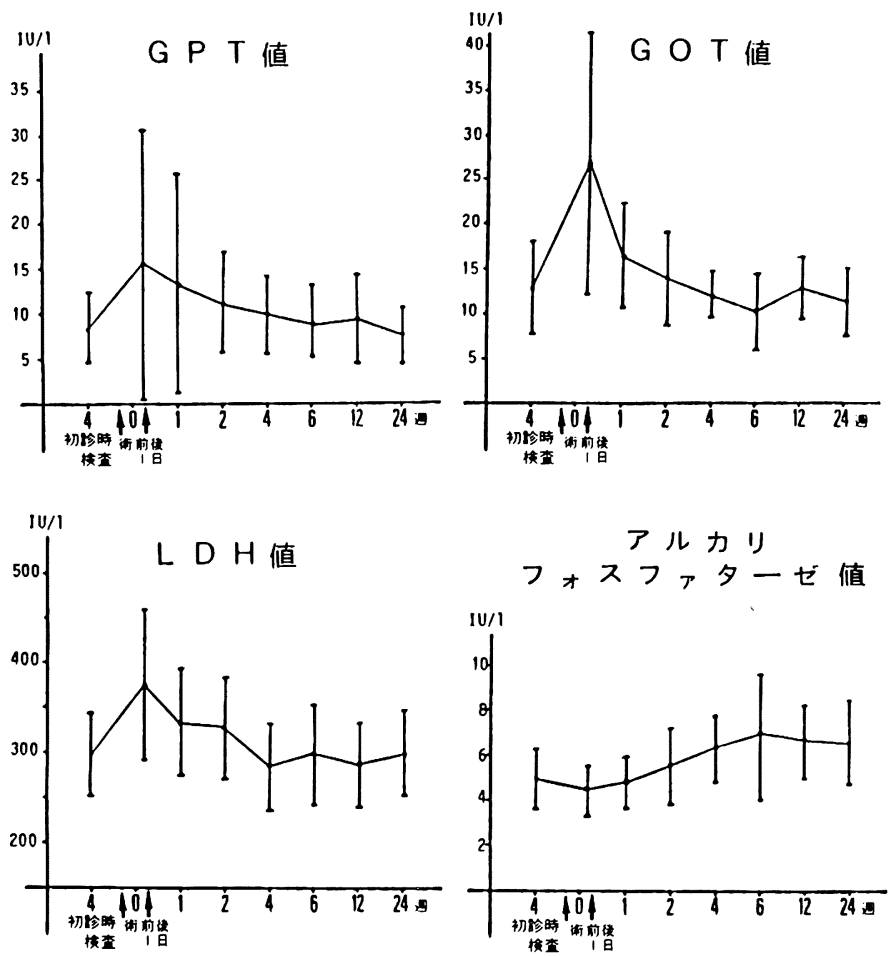

图 3 䀒機能検查成績の経日的变化（45例平均）

サイドガスによる消起を行い，また採血者の手指を清潔 に保つことに留意する（写真 2，3）.

手術は必要汇応して低血圧麻酔を行い, 中心静脈圧測 定用カテーテルなど，各種モニターを装着した監視下で 行ら。術中出血に対しては出血量を補填するよら早期よ り輸血を開始する．輸血にあたっては，まず少量の輸血 を行い，ハルーンカテーテルより血色素尿の出現の有無 をしらべ,それがいしとを確認してから輸血を行らこ とにしている.

\section{結果}

自家血輸血の施行症例は1983年 7 月より1985年10月の 2 年 3 か月間において 45 例あり, 男性14例, 女性31例, 年龄は16〜 53歳, 平均24歳であった。手術は額稪正外科 40 例，頭蓋颜面外科 1 例（表 1 ），影骨再建外科 4 例で あった. 採血量は 1 回 $270 \mathrm{gr}$ から 3 回 $1,500 \mathrm{gr}$ であり 平均1.84回 $680 \mathrm{gr}$ であった。一方, 出血量は $109 \mathrm{gr}$ か

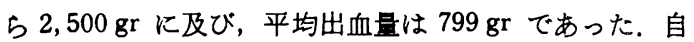
家保存血輸血は全例に施行されたが 7 例は自家保存血の みでは不足で一般輸血用の同種血が平均 4 単位榆血され た。

图 2 は全例の血液検査成績の平均値を示したものであ
る. 赤血球数, ヘマトクリット值, 血色素量, 血清鉄值 などは術後 1 日目に最低を示したが，術後早期より漸增 傾向を示し，術後 6 週でほぼ術前の值に回復した，血小 板数は採血にもかかわらずほとんど变化を示さなかった が, 術後 1 日目で最低を示し，その後急速に回復した。 鉄結合能は術後長期間にわたり増加傾向を示した（図 2).

GOT, GPT, LDH の値は術後 1 日目に最高を示し， 術後 4 週でほぼ衍前の值に復する傾向を認めた（图了）. 術後肝機能値に異常を示したのは 3 例で，いずれる術直 後より, GPT, GOT, LDH 值などの上昇をみたが, 比 較的早期で正常值に復したことから薬物誘発性肝炎と診 断された。な扰街に HBs 抗原の陽性化をきたした症 例は 1 例もなかった。

\section{考察}

第 2 次世界大戦後，麻酔，輸血および抗生物質の登場 により外科学は急速に発達し, 必然的に手術対象の抬大 をみた，すなわち生命を左右する多くの疾患の根治的手 術に止らず，身体の機能的・形態的異常に対する修正手 術が数多く行われるよらになった，䫑顔面変形症患者は 一般に全身的異常をもたず，その機能と形態異常に対す 
る修正手術は比較的若年で施行されることが多い，最 近, 顯顔面変形症に対する手術が著しく進步し ${ }^{28,30), ~ よ ~}$ り良好な成績をらるため, 複雑かつ精密な手術が行われ るよらになったので術中出血量の增加をきたし，輸血の 実施されることが多くなっだ25)（しかし，このような手 術に際して術中, 術後に同種血輸血を行い, 輸血後肝炎, さらには，ATL，AIDSなぞ生命の予後を悪くするよう な疾病を発病させては手術の効果は相殺され，結局患者 を不幸に陥れることになる。

輸血後肝炎は同種血輸血例の䄪 $15 \%$ 亿発生し，その大 部分が非 A 非 B 型肝炎であり，しかも発病者の $15 \%$ に肝 炎の遷延化がみられるといわれている がら現在, 非 A非B型肝炎ウイルスは同定されておら ず，したがってこれに対する確実な予防法は見出されて いない.

AIDS は1981年，米国で第 1 例が報告された新しいウ イルス性感染症で，レトロウイルス科嘱するヒト T細 胞親和性ウイルス II 型 $(\mathrm{HTLV}-\mathbb{I})$ が感染して，へル パーT細胞を破缺することにより免疫不全をきたすとい われている，米国に打いて発病者は10か月ごとに倍增し つつけけ，1985年10月で 14, 125例 ${ }^{32,33)}$ の発病者, HTLVIII抗体検査からの推定では $500,000 \sim 1,000,000$ 人（米国 民の $0.2 \sim 0.5 \%$ ）の無症候性キャリアーの存在 ${ }^{34)}$, 約 50 \%の死亡率，潜伏期が成人で29か月，小览で12か月など の事実が明らかとなっている35)。さらに注目すべきこと は発病者の約 $2 \%^{38)}$ が輸血による HTLV-III感染に起 因し，この割合は今後さらに增加していくあのと考えら れている，厚生省は1985 年10月，日本国内の AIDS 患 者11例を認定しており ${ }^{37}$ ，輸入血液製剤の大量使用，多 数の HTLV-I キャリアーの存在などにより ${ }^{14)}$ ，今後本 症患者の激増が予想されることから，日本における AIDS 対策が火急を告げている ${ }^{15,37)}$

ATL は 1977 年, 内山ら ${ }^{8,8)}$ により提唱され，その後 AIDS と深い関連のある HTLV-II と近縁の HTLV-I すなわち ATLV（成人 T 細胞白血病ウイルス）の感染に よりT細胞が無制限に增殖する疾患であることが明らか となった，本疾患は日本では九州を中心とした西日本に 多発し, 大河内 ${ }^{13}$ 比より, 抗 ATLV 抗体陽性率は長崎, 鹿児島で $3 \sim 5 \%$ ，本州で0.1 0.5\% と推定され，さら に, これら無症候性キャリアーの ATLV が輸血により 高頻度で感染することが明らかにされた。このよらに同 種血輸血により新たなキャリアーをつくることは次世代 への感染源を人為的に增やすことになるので一刻も早 く，輸血によるATLV 感染の予防対策かとられる必要 がある15)

このほか，輸血により感染する疾患として梅毒，マラ リア，トキソブラズマ，トリパノソーマ，サイトメガロ ウイルス, EB ウイルス, プルセラ, サルモネラなどが ある ${ }^{38)}$.
自家血輸血は，前述のごとき同種血輸血における病原 体で污染された血夜による各種疾患の発生を防止できる ばかりでなく，不適合輸血の防止，同種血輸血後の抗 体産生の防止，免疫反応に上る種々の輸血合併症の防 止 ${ }^{38 \sim 42)}$, 採血後に血夜希釈状態となるため微小循環の改 善 ${ }^{26)}$ 之血栓塞栓の予防，まれな血液型で輸血予定の場合 における適合血夜を見出す学苦不要，宗教的制限，たと えばエホバの民信者の一部にも輸血可能など多くの利点 を有する ${ }^{18 \sim 27)}$.

自家血輸血には保存血を用いる方法と凍結血を用いる 方法があるが，前者は特別な設備や処理を必要とせす， 小規模な病院でも実施可能などの特改を有するが，保存 期間が 3 週間と短く，採血量が最大 $1,200 \sim 1,500 \mathrm{gr}$ と 少ない欠点がある ${ }^{23)}$ ，一方，倲結血は採血後，長期間保 存可能なことから，採血量飞制限がないが，専門の人員 と高価な設備と複雑な処理を必要とする欠点 ${ }^{43)}$ がある.

わたくしたちは，自家保存血を用いる自家血輸血の利 点に着目し，1983年 7 月以来, 頽顔面骨の骨切り術の施 行患者の45症例に本法を施行した。そ結果, 輸血後肝 炎は 1 例も発生せず, 輸血後の副作用, すなわちへモグ 口ビン尿, 発熱, 出血傾向, 電解質異常, 空気塞栓, 血 栓塞栓などす皆無で，本法の高い安全性を確認すること ができた。

䫛顔面骨の骨切り術は低血圧麻醉下に施行すれば大多 数の症例で出血量を最大でも $1,500 \mathrm{ml}$ 以下に抑えるこ とが可能である。この出血量は自家保存血の最大準備可

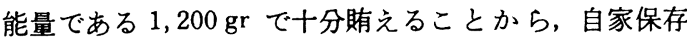
血輸血は顎矯正外科にきわめて適応しやすいものと考兄 られる ${ }^{25)}$ 。なお $400 \mathrm{gr}$ の自家保存血を準備すれば，下 影枝矢状分割法施行後，オトガイ形成術，舌骨上筋群切 離術，舌縮小術，上䫑オンレーなど補助手術の追加，さ らに骨間貫通ネジ骨接合術やミニプレートを用いる強力 な骨接合術の施行，骨切り骨片移動位置を確認するため の術中側面頭部X線規格写真撮影などを行っても，ほと んどの場合，術中出血量は $700 \mathrm{ml}$ までであり十分に対 処できる。このため，私たちは比較的小範囲の骨切り術 施行に際しても積極的に自家保存血を準備する方針をと っている。

出血量が $1,500 \mathrm{~m} l$ 以上と予想される場合では自家保 存血最大準備量 $1,200 \mathrm{gr}$ を用い，不足分については止 むを得ず同種血輸血を行っている。しかし，この場合て も，輸血後肝炎発生率は輸血単位数と高い相関を示すこ とから ${ }^{44)}$ ，同種血榆血単位数の減少化に大きな意味があ り，このことは血液銀行に批ける一般输血用血夜の節約 にも寄与するすのと考えられる.

自家血輸血の問題点は循環血液量の一過性の減少, 採 血血液の溶血と病原体による污染などである。これらの 対策として循環血液量の減少には採血直後，採血量と同 量のハルトマンD液の梌液, 溶血のチェックには輸血直 
後, へモグロビン尿出現の有無, 污染に対しては, 採血 時における䈯重な穿刺部皮虚の消毒, 術者の手指消毒, 使用器具の使用ごとの滅菌などを行い,さらに採血バッ クを乱暴に扱わず，施錠可能で庫内温度を記録でき，停 電時にも自家発電電源に自動的に切り替えられる血液保 存用冷蔵庫に保管などがある。

結

論

口腔・顎・顔面外科頋域の手術，とくに全身的に異常 かなく, かつ若年者に広く施行される顎矯正手術および 頭蓋顔面手術を中心として45症例に対して, 輸血後肝炎, ATL, AIDS などの感染および発症を防止するため, 保 存血を用いる自家血輸血を施行した，その結果，輸血後 肝炎は 1 例も発生せず，さらに本法の高い安全性を確認 しえた。このことから本法は口腔・顎・顔面外科領域に おける選択手術に今後広く応用されるべきものと考えら れる.

本論文の要旨は第 3 回顎変形症研究会（昭和59年 3 月

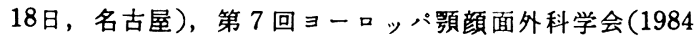
年 9 月 12 日，パリ）に扎いて報告した。

自家血輸血施行に際し，数々のこ教示ここ指遵を賜っ た九州大学医学部附属病院㭘査部, 輸血部, 大河内一雄 教授に厚くお礼申し上げます。

\section{引用 文 献}

1）高橋庄二郎：顎顔面外科の現況，菌科学報 74 : 991-1001 1974

2) Tsuruki, T., Ishikawa, N., et al.: Autotransfusion in orthognathic surgery. Abstracts of 7 th. Europian Association for Maxillo-Facial Surgery in Paris: 154, 1984.

3）片山透: 手術と肝炎. 日本医師会䧴誌 84 : 141-145 1980 .

4）吉原なみ子：供血者の選択に必要な検査 2) HB 関連抗原 - 抗体 Medical Technology 11：5926011983.

5）菊地金男, 舘田 朗：輸血後䀒炎の現状とその 予防。医学のあゆみ 131：641-646 1984.

6) 片山透: 輸血後非 A 非 B 型䀒炎の診断基準. 日本榆血学会雑誌 31：316-320 1985.

7）志方俊夫：非 A 非 B 型吓炎。日本輸血学会雑誌 31: 213-218 1985.

8) Uchiyama, T, Sagawa, K., et al.: Adult Tcell leukemia; clinical and hematologic featurs of 16 cases. Blood 50: 481-492 1977.

9）高月清，藤原弘一：成人 $\mathrm{T}$ 細胞白血病と桷 血. Medical Technology 11: 756-757 1983.

10) Ammann, A., Cowan, M., et al.: Aquired immunodeficiency in an infant: possible transmission by means of blood products. Lancet 956-958 April 30, 1983.

11) Jaffe, H., Sarngardharan, M., et al.: Infection with HTLV- III /LAV and transfusion-associated immunodeficiency syndrome. JAMA 254: 7707731985.

12) Peterman, T, Jaffe, H., et al.: Transfusionassociatd aquired immunodeficiency syndrome in United States. JAMA 254: 2913-2917 1985.

13) Okochi, K., Sato, H., et al.: A retrospective study on transmission of adult $\mathrm{T}$-cell leukemia virus by blood transfusion: seroconversion in recipient. Vox Sanguinis 46: 245-253 1984.

14）栗村敬，土江秀明：獲得性免疫不全症候群 (AIDS) ウイルス. 日本輸血学会雑誌 31：2232291985.

15）畑中正一：渝血とウイルス感染；日本の現状， 総合討論. 日本輸血学会雑誌 31:230-231 1985.

16) Goldsmith, M.: Reactions and counter-reactions to transfusion-associated-AIDS. JAMA 251: 177-179 1984.

17）日沼頼夫：榆血とウイルス感染；日本の現状， 序論。日本輸血学会雑誌 31：205-206 1985.

18) Milles, G., Langston, H., et al.: Experiences with autotransfusion. Surg., Gynec., and Obstet. 115: 689-694 1962.

19) Turner, S.: Autologous blood for surgical autotransfusion. In proceedngs of the American academy of orthopaedic surgeons. J Bone and Joint Surg 50-A: 8341968.

20) Newman, M., Hamstra, R., et al.: Use of banked autologous blood in elective surgery. JAMA 218: 861-863 1771.

21) Cowell, H., Swickard, J., et al.: Autotransfusion in children's orthpaedics. J Bone and Joint Surg 56-A: 908-912 1974.

22) Viviani, G., Sadler, J., et al.: Autotransfusion in scoliosis surgery. Clin Orthop 135: 74-78 1978.

23）小能忠教，金田清志，他：低血王麻酔下，自家 血輸血儿よる脊柱側症手術.臨整外 16:9189261981.

24）岡野克紀，飛松治基，他：整形外科選択手術に 対する自家血輸血の怪臨。整形外科 35：42-46 1984.

25）鶴木隆，石河信高，他：顎智正外科における 自家血輸血の応用について. 顎变形症誌 3:46491984

26）高折益彦, 福井明, 他：自己輸血。麻配 34 ： 530-550 1985.

27）藤原捻泰，桃井康晴，他：整形外科選択手術に おける自己血輸血の応用. 整形外科 36：182318271985.

28) Sebastier, R.: Personal communication in 
Erlangen. 1985.

29) H. Obwegeser, 高橋庄二郎監修：顎顔面外科 の発達に扣ける菌科医学の役割。苗界展望 51 : 915-922 1978.

30）鶴木 隆, 高橋庄二郎: 顎矯正外科の現況. 紫 耀 31: 1-10 1983.

31）輸血後䀒炎研究斑：厚生省血液研究事業, 昭和 57年度報告集 38-64 1983 .

32) Ludtke, M.: AIDS; a spreading scourge. TIME: 38-39 Aug. 51985.

33) Kroon, R., Wright, J.: A Scourage spreads panic. TIME: 18-20 Oct. 281985.

34) 北村 敬: AIDS (後天性免疫不全症候群)。 日 本医事新報 3189：27-34 1985.

35) Delany, P, Leviton, J., et al.: AIDS: growing threat. TIME: 52-58 Aug. 121985.

36) Marwick, C.: AIDS-associated virus yields data to intensifying scientific study. JAMA
254: 2865-2870 1985.

37）医学界新聞：火急を告げる日本の AIDS. 日本 医学界新聞 1680号：4 1985年.

38）栗村 敬, 土江秀明：輸血に必要なウイルス学. 日本医事新報 3187：128-129 1985.

39）川越裕也：日本血液学全書 10 , 血液型と輸血. 第 1 版, 丸善, 東京, 1977，237-265面.

40）小松文夫：輸血副作用と検査. Medical Technology 11: 679-689 1983.

41）安田純一：まれな血液型と輸血. Medical Technology 11 718-719 1983.

42）森田重三：遅発性溶血性輸血副作用. Medical Technology 11: 736-737 1983.

43）隅田幸男：日本血液型全書 10 , 血液型と輸血. 第 1 版, 丸善, 東京, 1977, 267-294頁.

44) 浜 六郎：輸血肝炎発生率と輸血単位数との相 関および輸血肝炎予防対策について。 日本輸血 学会雑誌 28：470-472 1982. 